\title{
Short-term recovery of soil physical, chemical, micro- and mesobiological functions in a new vineyard under organic farming
}

\author{
E. A. C. Costantini, A. E. Agnelli, A. Fabiani, E. Gagnarli, S. Mocali, S. Priori, S. Simoni, and G. Valboa \\ Consiglio per la Ricerca in Agricoltura e l'Analisi dell'Economia Agraria - Centro di Ricerca per \\ l'Agrobiologia e la Pedologia (CRA-ABP), Piazza Massimo D’Azeglio 30, 50121 Firenze, Italy
}

Correspondence to: G. Valboa (giuseppe.valboa@entecra.it)

\author{
Received: 4 November 2014 - Published in SOIL Discuss.: 11 December 2014 \\ Revised: 21 April 2015 - Accepted: 6 May 2015 - Published: 16 June 2015
}

\begin{abstract}
Deep earthwork activities carried out before vineyard plantation can severely affect soil profile properties. As a result, soil features in the root environment are often much more similar to those of the underlying substratum than those of the original profile. The time needed to recover the original soil functions is ecologically relevant and may strongly affect vine phenology and grape yield, particularly under organic viticulture.

The general aim of this work was to investigate soil resilience after vineyard pre-planting earthworks. In particular, an old and a new vineyard, established on the same soil type, were compared over a 5-year period for soil chemical, physical, micro- and mesobiological properties.

The investigated vineyards (Vitis vinifera L., cv. Sangiovese) were located in the Chianti Classico district (central Italy), on stony and calcareous soils, and were not irrigated. The older vineyard was planted in 2000, after slope reshaping by bulldozing and back-hoe ploughing down to about $0.8-1.0 \mathrm{~m}$. The new vineyard was planted in 2011, after equivalent earthwork practices carried out in the summer of 2009. Both vineyards were organically managed, and they were fertilized with compost only every autumn $\left(1000 \mathrm{~kg} \mathrm{ha}^{-1}\right.$ per year). The new vineyard was cultivated by periodic tillage, while the old vineyard was managed with alternating grass-covered and tilled inter-rows.
\end{abstract}

Soil samples were collected at $0-15 \mathrm{~cm}$ depth from fixed locations in each vineyard every spring from 2010 to 2014. The old vineyard was sampled in both tilled and grass-covered inter-rows.

According to the results from physical and chemical analyses, the new vineyard, during the whole 2010-2014 period, showed lower total organic carbon, total nitrogen, carbon to nitrogen ratio and electrical conductivity, along with higher silt and total $\mathrm{CaCO}_{3}$ contents than the old vineyard, suggesting still-evolving equilibrium conditions.

The microarthropod analysis showed significantly different abundances and community structures, in relation to both vineyard and time. Rainfall appeared to have an enhancing effect on microarthropod abundance, but only in the old vineyard, where the biota was more structured than in the new one. The euedaphic forms, well adapted to soil life, were always rare. Microbiological analysis revealed a different structure of eubacterial communities between the old and the new vineyard in the whole period. However, the DGGE similarity values of these communities increased by about $2.5 \%$ per year, suggesting that at least 3 years more are needed to compare intra- and inter-specific diversity of the two vineyards.

In conclusion, the consequences of deep earthworks on soil chemical, micro- and mesobiological properties were still evident 4 years after planting, indicating that more time is necessary for the recovery of soil functions, probably longer than the time needed to reach a state of economically viable grape production. 


\section{Introduction}

Soil is an essential factor in terroir expression, having a unique role in water and nutrient supply that strongly relates to the vine growth and quali-quantitative yield performance (Vaudour, 2002; Van Leeuwen et al., 2004). A soil management strategy that ensures proper soil physical conditions, organic matter turnover, adequate and balanced nutrient availability, and biological diversity is therefore important for maintaining adequate soil functionalities and highquality wine production (Van Leeuwen and Seguin, 2006; White, 2003). Most vineyards are established after the soil has been treated by deep tillage in order to break and loosen the soil and the underlying rock, create a workable planting bed, and incorporate the residues from the preceding cultivation and/or organic fertilizers. Slope-reshaping activities may also be implemented to overcome slope limitations by means of heavy machinery that moves the soil from the upper to the lower slope positions, or create terraces (Bazzoffi et al., 2006; Ramos and Martínez-Casasnovas, 2007). Earthwork practices, when applied without taking into account the site-specific soil and environment conditions, may severely impact soil quality, threatening soil productive potential and ecosystem functions (Le Bissonnais et al., 2002; Costantini and Barbetti, 2008; Martínez-Casasnovas and Conceptión Ramos, 2009; Garcia-Ruiz, 2010). This is of particular concern in hillside areas, using tillage practices that involve stripping or overturning the soil profile, which results in the disturbance of soil layers and outcropping of the underlying unweathered rock or sediment. The process may lead to higher soil susceptibility to erosion and intense physical, chemical and biological modifications in the root environment, e.g., mixing of soil horizons, alteration of soil structure and hydrology, loss of organic matter, modification in soil $\mathrm{pH}$, organic matter depletion, enrichment of salt concentration and calcium carbonate content, reduction of soil depth, water retention capacity, nutrient availability, and biological activity and diversity (Ramos and Martinez-Casasnovas, 2006; Le Bissonnais et al., 2007; Bazzoffi and Tesi, 2011; Costantini et al., 2012; Seddaiu et al., 2013; Sharp-Heward et al., 2014). The degree to which soil quality is altered by earthworks depends upon the soil type, climate and management practices.

The inherent ability of a soil to counteract degradation and restore new equilibrium conditions, in which productive performances and ecosystem functioning are not significantly different from those before disturbance, is known as "soil resilience" (Lal, 1997). Soil resilience is a soil-specific attribute of great ecological relevance, depending on a complex dynamic interaction of soil physical, chemical and biological processes (Seybold et al., 1999; Blanco-Canqui and Lal, 2008), that may strongly affect not only soil health but also vine phenology and grape yield (Rawnsley, 2014).

However, the recovery of soil functions assumes a specific meaning when applied to vineyard plantation on lands of an- cient agricultural use, like most of those used for viticulture in Europe, where only a marginal proportion of the new vineyards is planted on non-agricultural lands. In this context, whenever a new vineyard is established in the same place as the old one, the time needed to reach a new equilibrium should be assessed with reference to the previous conditions.

Organic farming is deemed to improve soil conditions in vineyards and speed up the recovery time in new vineyards, through the improvement of soil biological fertility (Huber et al., 2003; Reinecke et al., 2008; Probst et al., 2008). Furthermore, the organic treatments act both directly and indirectly, as they contribute to the preservation of more favorable moisture conditions to soil biological activity. Nevertheless, organic viticulture may have limitations in the recovery of some soil functions, in particular nitrogen nutrition of vines in very poor soils, like those affected by bulldozing and scalping (Costantini et al., 2013a).

Monitoring the degree of soil degradation and resilience over time requires the use of suitable soil quality indicators. These are commonly based on a variety of soil chemical, physical and biological properties that have a direct link to soil ecosystem functions and are highly responsive to soil perturbation, such as soil organic matter, aggregate stability, microbial respiration, biological activity and diversity.

The structure and functions of microbial communities are key drivers of soil biogeochemical cycles and general soil quality (Nannipieri et al., 2003); therefore the use of proper microbiological indicators is essential to assess their role in soil resilience (Bloem et al., 2006).

More recently, new bio-indicators involving the characterization of soil arthropod communities have been proposed for soil quality assessment. Microarthropods, in particular, are a major component of soil biota and are known to be important contributors to soil formation, organic matter transformation, nutrient cycling, $\mathrm{C}$ accumulation and plant and microbial diversity. Furthermore, they respond significantly to changes in land management and are thus gaining increasing interest as effective indicators of soil quality (Brussaard et al., 1997; Culliney, 2013; Parisi, 2001; Parisi et al., 2005).

The abundance and diversity of soil fauna integrate soil physical, chemical and microbiological properties and reflect general ecological changes, becoming an important asset in the landscape ecology and conservation tool box (Menta et al., 2008; Yan et al., 2012; Wardle, 2002). The spatial distribution of soil microarthropods and their functional groups' abundance are influenced by human-induced disturbance related to farming activities, such as soil cultivation (Paoletti and Bressan, 1995).

Our research was based on the monitoring of soil quality over time by means of chemical, micro- and mesobiological indicators, with the aim to assess the time required for a vineyard soil under organic farming to recover its functions after disturbance by pre-planting earthworks. In this paper, the results from the first 5 years of study are presented. 

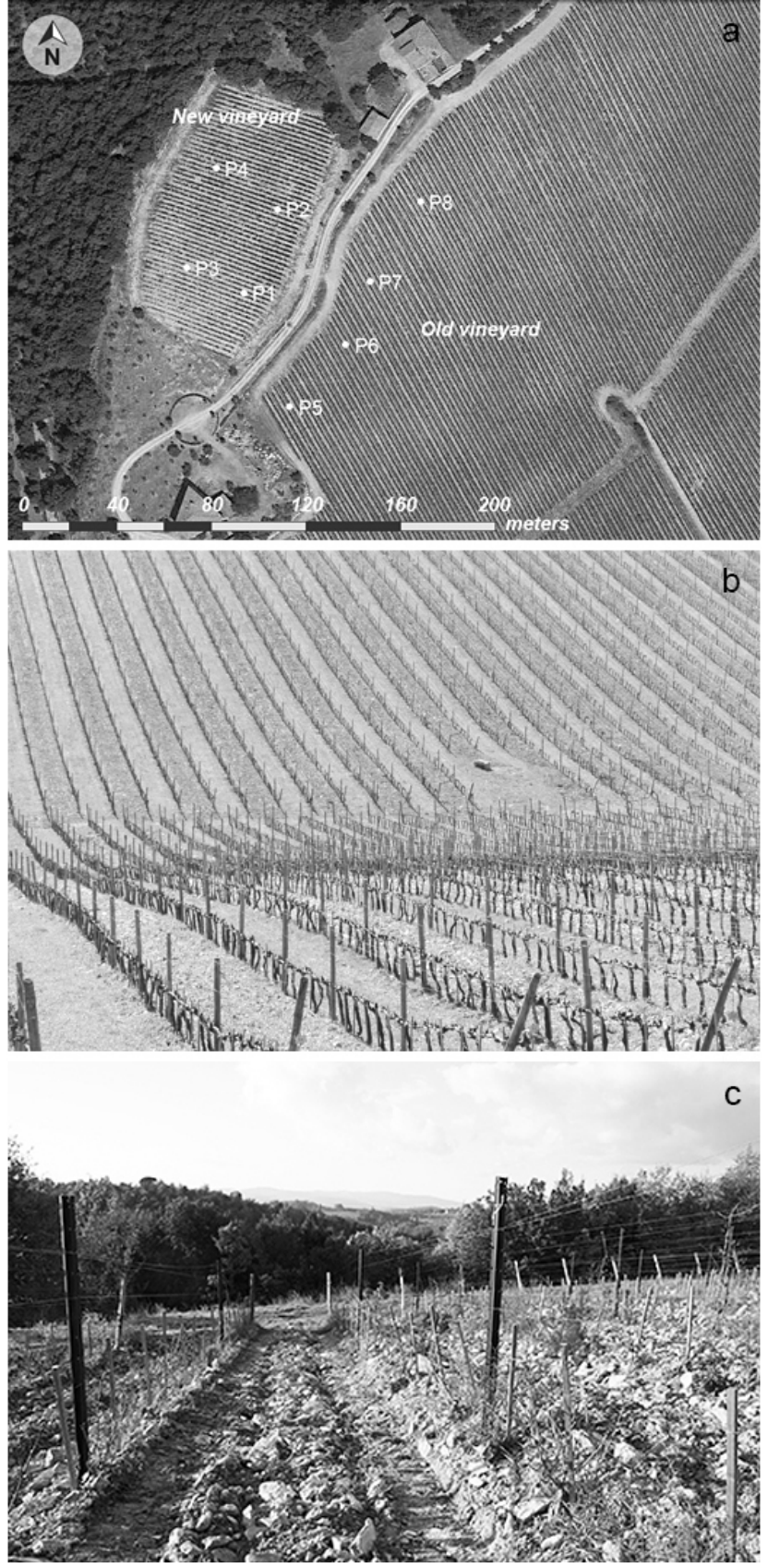

Figure 1. The old $(\mathbf{a}, \mathbf{b})$ and the new $(\mathbf{a}, \mathbf{c})$ vineyards with their respective monitoring plots (P1-P5 in the new vineyard, P6-P8 in the old vineyard).

\section{Materials and methods}

\subsection{Site characteristics and experimental design}

The surveyed vineyards belong to a premium wine farm, within the Chianti Classico district, in the northern part of the Siena Province (Tuscany, central Italy; $43^{\circ} 23^{\prime} 19^{\prime \prime} \mathrm{N}$, $11^{\circ} 26^{\prime} 66^{\prime \prime} \mathrm{E}$ ). The vines (Vitis vinifera $\mathrm{L}$. cv. Sangiovese) are grown on the top of a small hill, with a gentle slope (near
$5 \%$ ), at about $400 \mathrm{~m}$ a.s.l. altitude. The area is dominated by clayey-calcareous flysch lithotype, with stony and calcareous soils classified as Cambic Skeletic Calcisol (Loamic, Aric) (IUSS Working Group WRB, 2014).

The climate is Mediterranean suboceanic (Costantini et al., 2013b), characterized by cool and rainy winters, with minimum monthly average air temperatures close to $0^{\circ} \mathrm{C}$, but hot summers, with a large number of days experiencing maximum temperatures above $30^{\circ} \mathrm{C}$ (on average, 8.3 days in June, 17.5 days in July, 17.3 days in August, and 2.8 days in September). Based on the long-term average data (1990-2010 period), mean annual temperature is $12.3^{\circ} \mathrm{C}$ and precipitation $800 \mathrm{~mm}$, mostly concentrated in autumn and spring. The potential evapotranspiration (ET0) from April to September is $850 \mathrm{~mm}$ (Hargreaves and Samani, 1982), and the Winkler index is 1.856 degree days. Climate data were collected from a weather station located close to the site.

The experimental area (Fig. 1a, b, c) extends to approximately 40 ha and consists of two zones: one has a southwestfacing aspect, covered by a 14-year-old vineyard, planted in 2000 after slope reshaping by bulldozing and back-hoe ploughing down to about $0.8-1.0 \mathrm{~m}$; the other one, with a northwest aspect, is covered by a new vineyard established in 2011 after equivalent earthworks, carried out in the summer of 2009.

As according to ordinary management practices, the vineyards are periodically uprooted and re-planted, with a rest period between one vineyard and the following one. In the present case, before the establishment of the new vineyard, the soil had been covered by an older vineyard until 1990, followed by a set-aside period up to 2009. During this period, the soil was kept in a state of abandonment, allowing for the development of shrubs, weeds and wild vine plant vegetation.

Over the whole duration of the experiment, the new vineyard was entirely cultivated by periodic tillage, according to the farm strategy of keeping the soil surface free of weeds until the start of a commercial level of grape production.

The old vineyard was managed with alternating tilled $(\mathrm{T})$ and grass-covered (G) inter-rows; the latter were kept under natural weed development, which was periodically mowed (two or three times per year), shredded together with plant residues and spread on the soil surface. Once a year, the grass-covered soil was scarified to $40-50 \mathrm{~cm}$ depth without soil inversion so as to allow soil aeration and avoid soil compaction.

Vine disease control was based on copper treatments. This aspect was not studied, but in any case no particular fungal or pest disease was recorded during the study period. Overall, in the new vineyard there has been comparatively less machine traffic because of a lower need for plant management and protection treatments, due to the lower plant development and poor grape yields. Despite that, possible trafficrelated differences between the two vineyards are assumed to be negligible, since soil mechanical stress in the old vineyard 
Table 1. Main soil properties of the experimental area under ordinary vineyard management and grape production.

\begin{tabular}{lcccccccc}
\hline $\begin{array}{l}\text { Profile } \\
\text { horizon }\end{array}$ & $\begin{array}{c}\text { Depth } \\
\mathrm{cm}\end{array}$ & $\begin{array}{c}\text { Sand } \\
\%\end{array}$ & $\begin{array}{c}\text { Silt } \\
\%\end{array}$ & $\begin{array}{c}\text { Clay } \\
\%\end{array}$ & $\begin{array}{c}\mathrm{pH} \\
\mathrm{CaCO}_{3} \\
\%\end{array}$ & $\begin{array}{c}\mathrm{TOC} \\
\%\end{array}$ & $\begin{array}{c}\mathrm{TN} \\
\mathrm{gkg}^{-1}\end{array}$ \\
\hline Ap & $0-28$ & 26 & 35 & 39 & 8.3 & 25.3 & 0.81 & 0.83 \\
$\mathrm{Bw}$ & $28-100$ & 30 & 28 & 42 & 8.3 & 27.5 & 0.61 & 0.65 \\
$\mathrm{BC}$ & $100-120$ & 28 & 29 & 43 & 7.9 & 27.5 & & \\
\hline
\end{tabular}

is reduced by the grass cover (this is one of the main benefits at which the grass covering is aimed).

Both vineyards were managed organically, with $1.0 \mathrm{Mgha}^{-1}$ of compost applied per year in autumn. The compost was a commercial pelletized product obtained by dry-composting of livestock manure, with the following properties: total $\mathrm{N}=3.6 \%$, organic $\mathrm{N}=2.8 \%$, total $\mathrm{OC}=33.4 \%, \mathrm{C} / \mathrm{N}=9.3$, humic + fulvic acids $=15.2 \%$, total $\mathrm{P}\left(\mathrm{P}_{2} \mathrm{O}_{5}\right)=3.3 \%$, and total $\mathrm{K}=0.28 \%$ (s.s).

Four soil profiles per vineyard were dug close to the experimental plots in order to describe, analyze, and classify soil types. In the old vineyard, two of them were dug in the grass-covered inter-rows and the other two in the tilled interrows. No study of soil profile was performed at a detailed scale prior to 2009 earthworks; however, an antecedent soil survey of the entire farm indicated that the soil type across the selected vineyards was uniform. Table 1 shows the main features of the representative soil type of the experimental area, under ordinary viticultural management and grape production.

The monitoring of soil chemical, physical and biological properties over time was carried out by means of representative samples, collected annually from each vineyard in four selected $10 \mathrm{~m}^{2}$ georeferenced plots (referred to as $\mathrm{P} 1-\mathrm{P} 4$ in the new vineyard and P5-P8 in the old vineyard, Fig. 1a). Each plot was sampled during spring at four separate points, using different sampling procedures depending on the specific analyses to be performed (details are provided in the following paragraphs). The sampling locations were the same for the whole duration of the experimentation. The old vineyard was sampled in both grass-covered (P5 and P7 plots) and tilled inter-rows (P6 and P8 plots). In this regards it must be pointed out that, during the study period, no significant differences for selected soil properties were observed between the two inter-row managements $(P<0.05)$. This was determined by the fact that extensive weed development promoted by the autumn-spring rainfall often occurred also in cultivated spaces, and that soil sampling was always performed before the first grass mowing. For this reason, the grass-cover and tillage data were pooled together for all statistical evaluations.

Experimental data were not available for soil microarthropods in 2010 (both vineyards) and for soil properties in 2011 (old vineyard); therefore, for the mentioned years, not all selected variables could be considered.
Neither vine phenology nor production were recorded during the 5 years, since in the old vineyard, owing to the youth of plants and delayed growth caused by poor soil conditions, no significant grape production was achieved until the end of the experimental period, except for a few small clusters in 2013 and 2014, which were, however, not suitable for harvest or grape yield monitoring.

\subsection{Soil physical and chemical analysis}

For soil physical and chemical monitoring, each experimental plot was sampled by digging four $15 \mathrm{~cm}$ depth pits, from which disturbed soil samples were collected. The samples from the different sampling points were mixed thoroughly to provide a single composite sample per plot.

Before laboratory analyses, the samples were air-dried and sieved through a $2 \mathrm{~mm}$ mesh. For $\mathrm{C}$ and $\mathrm{N}$ determination, subsamples were ground and homogenized to $0.5 \mathrm{~mm}$. Specifically, soil texture was determined using the SediGraph method (Andrenelli et al., 2013). Total organic C (TOC) and total N (TN) were measured by dry combustion on a Thermo Flash $2000 \mathrm{CN}$ soil analyzer. To this aim, $70 \mathrm{mg}$ soil was weighed into Sn-foil capsules to determine the total C (organic $\mathrm{C}+$ mineral C) and $\mathrm{N}$ contents. Separately, 20 to $40 \mathrm{mg}$ soil was weighed into Ag-foil capsules, pre-treated with $10 \%$ $\mathrm{HCl}$ until complete removal of carbonates and then analyzed for total $\mathrm{C}$ content (corresponding to the whole OC content). The total equivalent $\mathrm{CaCO}_{3}$ content was calculated from the difference between the total $\mathrm{C}$ measured before and after the $\mathrm{HCl}$ treatment (Sequi and De Nobili, 2000).

Active lime was determined according to the Drouineau method; the procedure involved reaction of the soil with $0.1 \mathrm{M}$ ammonium oxalate for $2 \mathrm{~h}$ under agitation, followed by the determination of unreacted oxalate by back-titration with $0.1 \mathrm{M} \mathrm{KMnO}_{4}$ (Loeppert and Suarez, 1996). Soil pH was measured potentiometrically in a $1: 2.5$ soil-water suspension. Electrical conductivity was measured in a $1: 2$ soilwater extract after $2 \mathrm{~h}$ of shaking, letting it stand overnight, and filtration. The main soil properties at the beginning of the study are reported in Table 2.

\subsection{Soil microbiological analysis}

Soil microbiological communities were characterized using subsamples of the same soil samples collected for soil physical and chemical analyses. 
Table 2. Soil properties of the selected monitoring plots within each vineyard in the first year of study (soil depth: 0-15 cm).

\begin{tabular}{lcclccccccccc}
\hline Vineyard & $\begin{array}{c}\text { Clay } \\
(\%)\end{array}$ & $\begin{array}{c}\text { Sand } \\
(\%)\end{array}$ & $\begin{array}{l}\text { USDA texture } \\
\text { class }\end{array}$ & $\begin{array}{c}\text { Field capacity } \\
(\% \mathrm{w} / \mathrm{w})\end{array}$ & $\begin{array}{c}\text { Wilting point } \\
(\% \mathrm{w} / \mathrm{w})\end{array}$ & $\begin{array}{c}\mathrm{TOC} \\
(\%)\end{array}$ & $\begin{array}{c}\mathrm{TN} \\
(\%)\end{array}$ & $\begin{array}{c}\mathrm{C} / \mathrm{N} \\
(\%)\end{array}$ & $\begin{array}{c}\text { Total } \mathrm{CaCO}_{3} \\
(\%)\end{array}$ & $\begin{array}{c}\mathrm{Active} \mathrm{CaCO}_{3} \\
(\%)\end{array}$ & $\begin{array}{c}\mathrm{pH}^{\mathrm{EC}} \\
(\mu \mathrm{S})\end{array}$ \\
\hline P1 new & 20.8 & 32.5 & Loam & 24.3 & 10.3 & 0.45 & 0.08 & 5.9 & 34.7 & 8.0 & 8.2 & 206.9 \\
P2 new & 18.9 & 33.1 & Loam & 22.9 & 9.8 & 0.43 & 0.08 & 5.6 & 37.6 & 8.8 & 8.3 & 166.0 \\
P3 new & 18.1 & 34.4 & Loam & 22.2 & 9.5 & 0.39 & 0.07 & 5.7 & 39.5 & 9.0 & 8.2 & 167.0 \\
P4 new & 20.7 & 35.1 & Loam & 22.3 & 9.6 & 0.47 & 0.06 & 7.6 & 40.9 & 7.3 & 8.2 & 171.8 \\
\hline P5 old-G & 25.1 & 31.7 & Loam & 24.8 & 12.3 & 0.68 & 0.10 & 6.8 & 27.8 & 6.1 & 8.2 & 211.3 \\
P6 old-T & 28.6 & 31.4 & Clay loam & 25.4 & 12.9 & 0.81 & 0.11 & 7.6 & 27.4 & 5.0 & 8.2 & 245.9 \\
P7 old-G & 26.4 & 31.9 & Loam & 24.7 & 13.3 & 0.65 & 0.10 & 6.8 & 21.7 & 4.3 & 8.2 & 186.0 \\
P8 old-T & 25.6 & 32.5 & Loam & 22.2 & 11.4 & 0.46 & 0.08 & 5.6 & 36.3 & 6.1 & 8.2 & 273.5 \\
\hline
\end{tabular}

Estimation of soil organic OC mineralization was done by measuring the $\mathrm{C}-\mathrm{CO}_{2}$ developed $[\mathrm{mg}(\mathrm{C}$ $\mathrm{CO}_{2}$ ) $\mathrm{kg} \mathrm{soil}^{-1} \mathrm{day}^{-1}$ ] from the soil in closed jars (Isermeyer, 1952). A $25 \mathrm{~g}$ amount of oven-dried soil was rewetted to a $-33 \mathrm{kPa}$ water tension and incubated at $30^{\circ} \mathrm{C}$. The $\mathrm{CO}_{2}$ evolution after 1 day (representing the soil easily mineralizable C) was determined by back-titration of the $\mathrm{NaOH}$-absorbed $\mathrm{CO}_{2}$.

The structure of microbial communities was determined by means of denaturing gradient gel electrophoresis (DGGE), a PCR-based molecular technique which has been widely used in microbial ecology for the rapid evaluation of soil microbial community structure of multiple soil samples (Muyzer and Smalla, 1998; Nannipieri et al., 2003). Soil DNA was extracted by means of the bead-beating method using a FastDNA SPIN kit and the FastPrep instrument (Bio 101, USA). The eubacterial community structure was determined by amplifying the $16 \mathrm{~S}$ rRNA genes, using the primer set GC-968f (5'-CGC CCG GGG CGC GCC CCG GGC GGG GCG GGG GCA CGG GGG GAA CGC GAA GAA CCT TA-3') and 1401r (5'-GCG TGT GTA CAA GAC CC-3') designed by Felske and Akkermans (1998). Soil template DNA was amplified with a mix containing $1 \mathrm{U}$ of Go Taq Flexi (PROMEGA), $6.25 \mathrm{pM}$ of primers, $6.25 \mathrm{mM}$ of deoxyribonucleotide triphosphates, $1.5 \mathrm{mM}$ of $\mathrm{MgCl}_{2}$ and a $25 \times$ reaction buffer in a final reaction volume of $25 \mu \mathrm{L}$. The PCR was then performed with a I-Cycler thermal cycler (BIORAD) with the following temperature cycle: $94^{\circ} \mathrm{C}$ denaturation for $90 \mathrm{~s}, 56^{\circ} \mathrm{C}$ annealing for $30 \mathrm{~s}$, and $72{ }^{\circ} \mathrm{C}$ extension for $45 \mathrm{~s}$, followed by 33 cycles at $95^{\circ} \mathrm{C}$ for $20 \mathrm{~s}, 56^{\circ} \mathrm{C}$ for $30 \mathrm{~s}$, and $72^{\circ} \mathrm{C}$ for $45 \mathrm{~s}$, and a final extension at $72^{\circ} \mathrm{C}$ for $7 \mathrm{~min}$. PCR products were checked on $1 \%$ agarose gel by electrophoresis.

The DGGE analysis was performed with the Ingeny PhorU system (Ingeny International, the Netherlands) on a $6 \%$ polyacrylamide gel (acrylamide/bis ratio, 37.5:1) under denaturation conditions (urea, $7 \mathrm{M} ; 40 \%$ formamide with a denaturing gradient ranging from 42 to $58 \%$ ); the gels were run in $1 \mathrm{X}$ Tris-acetate-EDTA buffer at $75 \mathrm{~V}$ for $16 \mathrm{~h}$ at $60{ }^{\circ} \mathrm{C}$ and were stained with $12 \mathrm{~mL}$ of $1 \mathrm{X}$ Tris-acetateEDTA buffer containing 1.2 $\mu \mathrm{L}$ of SYBR Green I (dilution,
$1: 10000)$ for $30 \mathrm{~min}$ in the dark. Visualization and digital pictures were created with a ChemiDoc system (Bio-Rad).

The DGGE patterns and band intensity were used to calculate the Shannon-Wiener index $\left(H^{\prime}\right)$ and the Simpson index $(D)$, which, along with the number of DGGE bands, were used to characterize soil microbial diversity:

$H^{\prime}=-{ }^{S} \Sigma_{i=1} p_{i} \ln p_{i}$,

$D=-{ }^{S} \Sigma_{i=1} p_{i}^{2}$,

where $S$ is the total number of bands and $p_{i}$ is the relative abundance of the $i$ band calculated as the ratio between $i$ band intensity and the sum of the intensities of all the bands.

Calculations were performed using Gel Compare II v4.6 software (Applied Maths) as described by Fabiani et al. (2009).

\subsection{Soil biological quality index (QBS-ar)}

Soil microarthropod communities were studied according to the procedure described by Parisi et al. (2005). Generally, the application of microfauna-based indicators of soil quality is often limited by the difficulties in classifying organisms to the species level. To overcome this limitation, Parisi et al. (2005) introduced a simplified eco-morphological index (EMI) based on arthropods for the determination of the index of soil biological quality (QBS-ar). This index is based on the concept that the higher soil quality, the higher the number of microarthropod groups adapted to the soil habitat. The degree of microarthropod adaptation is defined by specific morphological characters; in particular, more adapted organisms will typically show reduced pigmentation and visual apparatus, loss or reduction of wings, reduced appendages, and a streamlined body form (Parisi, 2001). Each biological form (morphotype) isolated from the soil can be classified to the order level and is eco-morphologically scored. The scoring is proportional to organism adaptation degree, ranging from 1 (surface-living organisms) to 20 (deep-living organisms). The sum of all EMI values for a given soil sample provides its QBS-ar index. Once determined, the QBS-ar values were used to define "soil biological quality class", according to the classification by D'Avino (2002). 


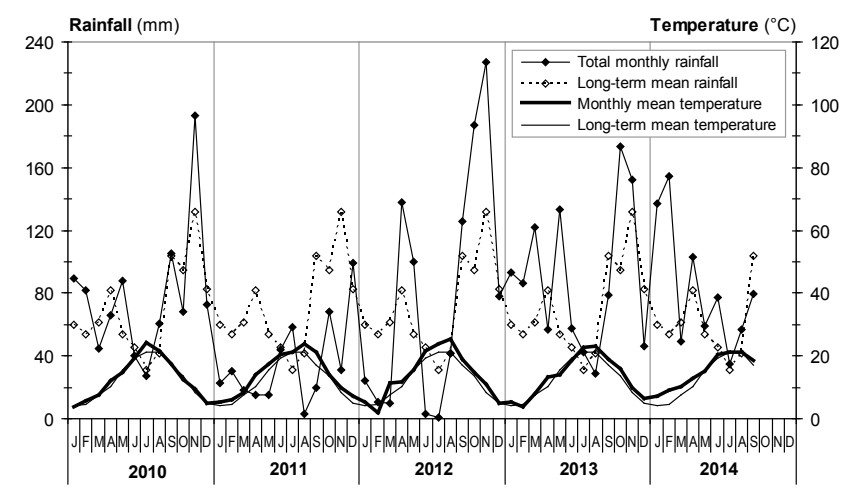

Figure 2. Rainfall and temperature during the experimental period with their respective long-term average trends (1990-2010).

In particular, each class was identified by a number, ranging from 0 to 7, which increases with increasing complexity and the adaptation degree of soil microarthropod communities as expressed by the QBS-ar ("class 0": absence of edaphic groups and occurrence of only surface-living arthropods and/or Holometabola larvae; "class 7": occurrence of at least three edaphic groups, including Protura and/or edaphobiont Coleoptera and QBS > 200).

Soil microarthropod communities were also characterized quantitatively by measuring the abundance of the main arthropod groups and the respective relative frequencies.

All biological determinations were performed once a year from 2011 to 2014 by collecting $1 / 3 \mathrm{dm}^{3}$ soil cores at 0 $10 \mathrm{~cm}$ depth from four replicated zones within each vineyard. For the extraction of microarthropods, the soil samples were placed in Berlese-Tullgren funnels for 5 days. The soil was allowed to dry from the top down by means of a heating light; the microarthropods moving through the soil were collected into a preservative solution ( $80 \%$ ethanol) and afterwards identified to the order level using a stereomicroscope.

\subsection{Statistical analysis}

Differences in soil properties between the new and the old vineyards were tested statistically by the non-parametric Kruskal-Wallis test to avoid inaccuracies due to variance heterogeneity and non-normality patterns in data distribution (Statsoft STATISTICA v. 7; SPSS v. 15.0). Soil QBS-ar data were analyzed using the Mann-Whitney rank test (SPSS v. $15.0 ; P=0.05)$.

A principal component analysis (PCA) was performed for each experimental year in order to explore similarities and differences between the two vineyards and to understand the pattern of interrelationships among selected soil parameters over time. A separate PCA was done for the whole 20102014 data set, with and without the inclusion of climate variables. The results are displayed graphically as score and loading plots. As previously mentioned in Sect. 2.1, most of soil chemical and microbiological data were not available in 2011
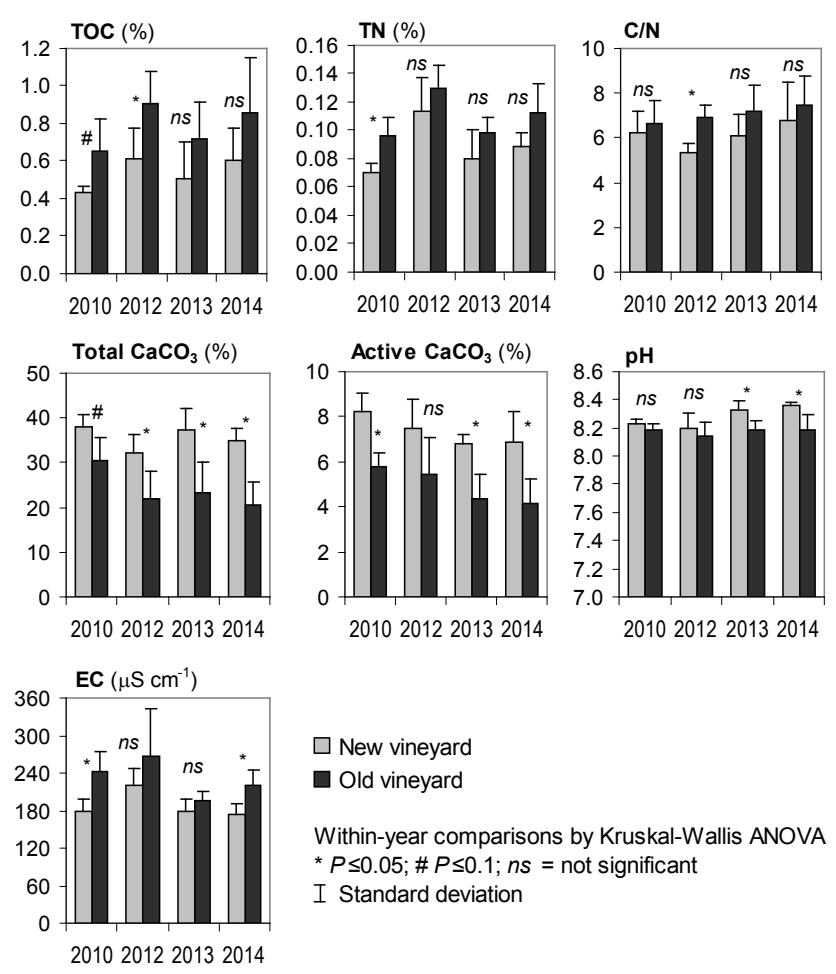

$\square$ New vineyard

Old vineyard

Within-year comparisons by Kruskal-Wallis ANOVA

${ }^{*} P \leq 0.05$; $\# \leq 0.1 ; n s=$ not significant

I Standard deviation

Figure 3. Soil chemical properties in the new and the old vineyard during the experimental period.

for the old vineyard; therefore, in order to perform the PCA, the old vineyard data set was completed by replacing the missing value of each variable with the average of that variable across all other trial years in the same experimental condition. This procedure is justified by the fact that PCA was mainly aimed at interpreting the phenomenon under study through new latent components resulting from the correlation among variables, and not classifying the values of the variables themselves (ISTAT, 2000).

\section{Results}

\subsection{Climatic conditions during the trial}

The trends of rainfall and temperature recorded during the monitoring period are shown in Fig. 2 with the respective long-term average trends.

In 2010, the temperature and rainfall values were close to the long-term means. Starting from 2011, the area was affected by highly variable annual precipitation, often with marked differences from the long-term means. In particular, 2011 was characterized by below-average rainfall over almost the whole year and strong drought conditions in $\mathrm{Au}-$ gust and September. There was above-average rainfall in spring and autumn in 2012, with an intense drought period in June-July. There was a moderate drought in August in 2013, with above-average precipitation from winter to spring and 


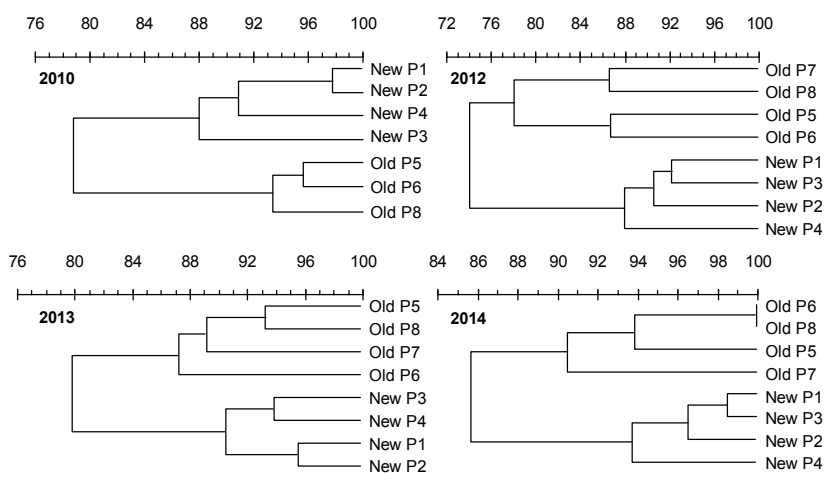

Figure 4. Dendrograms of hierarchical cluster analysis based on UPGMA and Dice's coefficient of DGGE banding patterns of the 16S rDNA.

in autumn. Finally, 2014 experienced above-average winter rainfall and moderate drought conditions in July.

\subsection{Soil physical and chemical properties}

Soil texture was quite stable over time: the clay and sand contents in each vineyard did not vary significantly from the beginning to end of the trial. However, the two vineyards revealed significant differences in the $<0.05 \mathrm{~mm}$ particle size fraction, with the new vineyard featuring a higher silt content $(47.3 \%$ compared to $41.2 \%)$ and a lower clay content ( $23.7 \%$ compared to $31.1 \%$ ). Averaged over the whole study period, soil texture classification varied between "clay loam" (old vineyard) and "loam" (new vineyard).

Almost all selected soil chemical properties followed temporal fluctuations (Fig. 3), with similar patterns in the two vineyards, thus suggesting the influence of common variability factors. Over the 5-year monitoring period, the new vineyard averaged lower TOC and TN amounts, with higher $\mathrm{CaCO}_{3}$ and $\mathrm{pH}$ values. The best discriminating soil variable was $\mathrm{CaCO}_{3}$ content, with differences falling in the ranges of 25-69 and 38-67\% for the total and the active pools, respectively. Soil TOC content averaged higher values in the old vineyard over the whole monitored period $(+33 \%)$, though the differences were statistically significant only in 2010 and 2012.

From 2010 to 2012, the two vineyards had similar soil $\mathrm{pH}$ values (8.2). In the following years, the new vineyard showed slight but significant $\mathrm{pH}$ increases, while the old vineyard confirmed substantial stability.

\subsection{Soil microbial activity and diversity}

The DGGE fingerprints showed complex banding patterns, indicating a high bacterial diversity, with a clear distinction between the two vineyards in each sampling year. The cluster analysis designated two distinct clusters for the old and the new vineyard (Fig. 4) with varying degree of similarity over

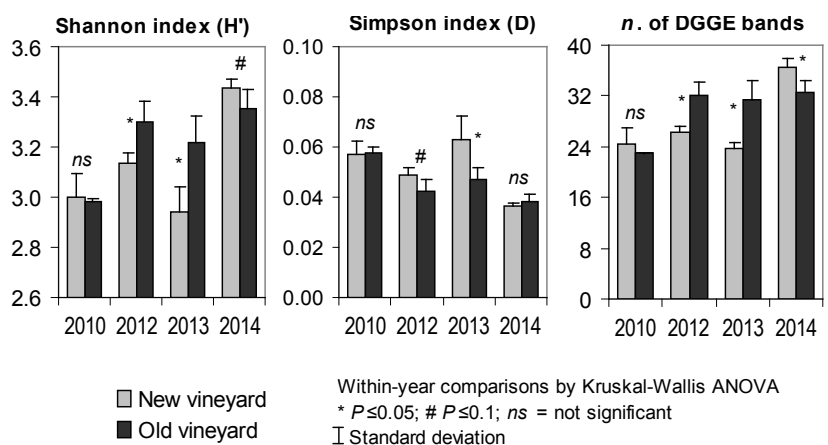

Figure 5. Diversity indices and number of bands of the DGGE banding patterns.

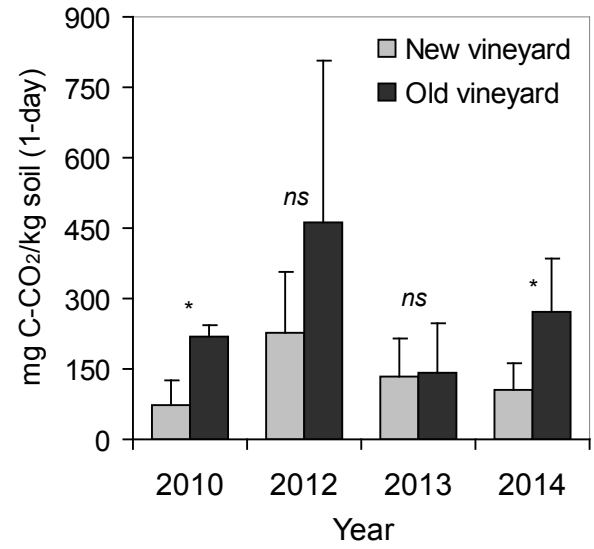

Within-year comparisons by Kruskal-Wallis ANOVA * $P \leq 0.05 ; n s=$ not significant

I Standard deviation

Figure 6. Microbial respiration in the two vineyards during the experimental period.

time. These differences indicate a clear effect of pre-planting earthworks on the composition of soil bacterial communities in the new vineyard, due to the redistribution of bacterial communities across the soil profile caused by the mixing of soil horizons (Eilers et al., 2012; Fierer et al., 2003). It is interesting to note that the similarity between the two main clusters increased from $2010(79 \%)$ to $2014(86 \%)$, thus suggesting a slow but constant increase in similarity between soil bacterial communities of the two vineyards.

The diversity indices displayed temporal variability, with unstable differences between the new and the old vineyard (Fig. 5). The latter had a similar (2010 and 2014) or higher (2012 and 2013) Shannon index compared to the former. The Simpson index showed no significant differences at the beginning and end of the experimental period, while during 2012 and 2013 it averaged higher values in the new vineyard (statistical significance levels $P=0.1$ and $P=0.05$, respectively). Furthermore, it decreased with time in both vineyards. The number of bands significantly differed between the old and the new vineyard (except in the year 2010), 

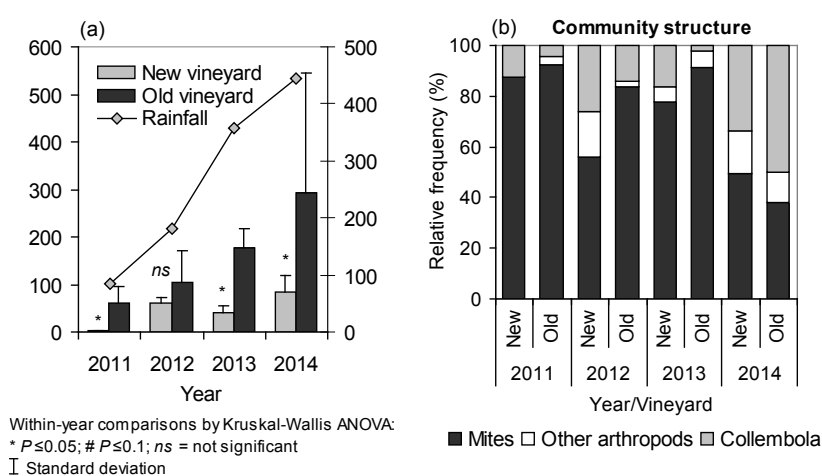

I Standard deviation

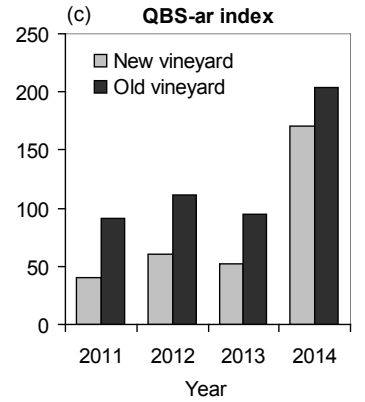

Figure 7. Abundance and community structure of soil microarthropods and soil biological quality index (QBS-ar) in the new and old vineyard over the experimental period. The annual abundance is shown together with the cumulative rainfall from January to April (before sampling).

confirming a different structure of bacterial communities; moreover, in contrast to the Simpson index, it increased with time (Fig. 5).

Microbial respiration (Fig. 6) was significantly higher in the old vineyard in 2010 and 2014 (by 61 and $66 \%$, respectively). A large difference also occurred in $2012(51 \%)$, which was, however, not statistically significant due to a high within-vineyard variability. In 2013, the two vineyards had comparable respiration values.

\subsection{Soil mesobiological quality}

As concerns microarthropod communities, more than 3000 organisms were extracted from the soil samples over the entire experimental period (Table 3). On the whole, arthropod abundance was relatively low in both vineyards; however, it averaged higher values in the old vineyard (only in 2012 was the difference not statistically significant), following an increasing trend with time until the end of the trial (Fig. 7a).

During the first 3 years, the relative distribution of the main mesofauna groups (mites, springtails and "other arthropods") was characterized by a large dominance of mites (over $50 \%$ ), with a higher frequency in the old vineyard (Fig. 7b). In contrast, in the last year, the frequency of collembolans was remarkably higher compared to that of the other groups, and the relative frequency of mites was higher in the new than in the old vineyard. The "other arthropods" always rep- resented a very small component of the mesofauna community.

According to the criteria proposed by D'Avino (2002), soil quality as evaluated by the QBS-ar index was always higher in the old vineyard (Mann-Whitney test: $U=58$; $P=0.008$ ) (Fig. 7c). The highest values of soil QBS-ar were measured in 2014, in the old vineyard (old vineyard: QBS-ar $=204, n$. taxa $=18$; new vineyard: QBS-ar $=171$, $n$. taxa $=12$ ). During the first 3 years, the QBS-ar values in the new vineyard were typical of low-quality soils (class IIIII, $n$. taxa $=2-5$ ); in the same period, higher QBS-ar values were registered in the old vineyard (class IV-VI, $n$. taxa $=6-$ 12). In all samplings, collembolans always included edaphic forms (e.g., Onychiuridae; EMI = 20). The considerable increase in QBS-ar index registered in the last experimental year in both vineyards (class VI in the new vineyard; class VII in the old vineyard) was mainly due to the presence of edaphic forms (Protura, Symphyla, Diplura, Pauropoda, Coleoptera).

\section{Discussion}

\subsection{Soil physical and chemical properties}

Earthwork operations carried out before planting in the new vineyard caused the disturbance of the soil layers and a surface enrichment of the silt-sized mineral particles originating from the mechanical grinding of the sedimentary marly rock of substratum. The overturning action of tillage caused a relatively higher $\mathrm{CaCO}_{3}$ level in the surface layer, which, combined with a lowered soil buffering capacity due to the organic matter depletion, may account for the tendency, even if slight, towards an increase in soil $\mathrm{pH}$ with time in the new vineyard.

The results indicate that, in the new vineyard, soil chemical conditions are still evolving and different from those of the old vineyard. It is difficult to foresee the time required to have similar soil $\mathrm{CaCO}_{3}$ values in the two vineyards, and even whether it will be ever possible. Lime dynamics, in fact, may vary greatly, depending on a number of factors controlling the dissolution/precipitation reactions and physical redistribution within the soil profile, such as climate (temperature, precipitations), water and dissolved $\mathrm{CO}_{2}$ availability, soil surface and subsurface hydrology, organic matter content, biological activity and soil management (Lamb, 1990; Egli and Fitze, 2001). On the other hand, the old vineyard also looks to be far from being in a steady state. It is interesting to note that both vineyards experienced a decrease in $\mathrm{CaCO}_{3}$ content over time. This can be, at least in part, attributed to modifications in soil carbonate equilibrium by intensified leaching processes, caused by above-average rainfall occurring during the last 3 years of the experimental period (Fig. 2).

As regards soil OC status, this depends upon the balance between degrading and restorative processes, which are 
Table 3. Abundance of soil microarthropods, number of taxa and QBS-ar index (as resulting from the sum of the EMI scores) in the old (OV) and in the new (NV) vineyard (2011-2014).

\begin{tabular}{|c|c|c|c|c|c|c|c|c|c|c|c|c|c|c|c|c|c|}
\hline & \multicolumn{8}{|c|}{ Microarthropod abundance } & & \multicolumn{8}{|c|}{ EMI (eco-morphological index) } \\
\hline & \multicolumn{2}{|c|}{2011} & \multicolumn{2}{|c|}{2012} & \multicolumn{2}{|c|}{2013} & \multicolumn{2}{|c|}{2014} & & \multicolumn{2}{|c|}{2011} & \multicolumn{2}{|c|}{2012} & \multicolumn{2}{|c|}{2013} & \multicolumn{2}{|c|}{2014} \\
\hline & OV & NV & OV & NV & OV & NV & OV & NV & & OV & NV & $\mathrm{OV}$ & NV & OV & NV & OV & $\mathrm{NV}$ \\
\hline Acari & 7 & 224 & 138 & 353 & 123 & 643 & 168 & 352 & & 20 & 20 & 20 & 20 & 20 & 20 & 20 & 20 \\
\hline Collembola & 1 & 11 & 65 & 60 & 26 & 14 & 114 & 466 & & 20 & 20 & 20 & 20 & 20 & 20 & 20 & 20 \\
\hline Araneida & & & & & & 1 & 1 & 1 & & & & & & & 1 & 5 & 5 \\
\hline Chilopoda & & & & 1 & & 2 & 3 & 17 & & & & & 10 & & 10 & 10 & 10 \\
\hline Coleoptera & & & & 1 & & & 1 & 1 & & & & & 15 & & 1 & 11 & 20 \\
\hline $\begin{array}{l}\text { Holometabolous } \\
\text { insect larvae }\end{array}$ & & & 41 & 3 & & 14 & 4 & 8 & & & & 10 & 10 & & & 10 & 10 \\
\hline Diplura & & 2 & & & 1 & & 4 & 2 & & & 20 & & & & 20 & 20 & 20 \\
\hline Diptera larvae & & 1 & 3 & 1 & 1 & 11 & 5 & 40 & & & 10 & 10 & 10 & 10 & 10 & 10 & 10 \\
\hline Hymenoptera & & & & 2 & & 2 & 2 & 26 & & & & & 5 & 1 & 5 & 5 & 5 \\
\hline Homoptera & & 1 & & 2 & & & & & & & 1 & & 1 & & 5 & & \\
\hline Protura & & & & 1 & & & 4 & 1 & & & & & 20 & & & 20 & 20 \\
\hline Symphyla & & 3 & & & & & 2 & 2 & & & 20 & & & & & 20 & 20 \\
\hline Thysanoptera & & & & & & 1 & & 1 & & & & & & & 1 & & 1 \\
\hline Diptera & & & & & 7 & 9 & & 1 & & & & & & 1 & 1 & & 1 \\
\hline Rincota & & & & & & 1 & & 4 & & & & & & & 1 & & 1 \\
\hline Pauropoda & & & & & & & 30 & 4 & & & & & & & & 20 & 20 \\
\hline Psocoptera & & & & & & & & 1 & & & & & & & & & 1 \\
\hline Diplopoda & & & & & & & & 2 & & & & & & & & & 10 \\
\hline Isopoda & & & & & & & & 1 & & & & & & & & & 10 \\
\hline Total arthropods & 8 & 242 & 247 & 424 & 158 & 698 & 338 & 930 & QBS-ar & 40 & 91 & 60 & 111 & 52 & 95 & 171 & 204 \\
\hline & & & & & & & & & $n$. taxa & 2 & 6 & 4 & 9 & 5 & 12 & 12 & 18 \\
\hline
\end{tabular}

strongly affected by the management system employed. In our case, both vineyards had a poor soil OM level, like most vineyards in the area under the same management (Costantini et al., 2013a). The level was lower in the new vineyard as a result of tillage-based management of the soil surface, which limited the potential for OM accumulation. In this regard, it must be considered that plant residues are here the main source of soil OM, and that the whole residue biomass provided by the young vines in the new vineyard is lower due to the reduced plant development.

Soil TN followed a similar trend to TOC (TN vs. TOC: $R^{2}=0.800^{* *}$ ), averaging lower contents in the new vineyard. The outcomes confirm the crucial role played by OM in soil $\mathrm{N}$ bio-availability, especially in farming systems not employing mineral fertilizers. Also, in this case, the significance of differences between the two vineyards was affected by a high variability within the vineyard.

Soil C/N ratio was quite low across the whole area, tending to be smaller in the new vineyard. Similar $\mathrm{C} / \mathrm{N}$ values have been reported by other authors for tilled vineyards on sloping land, under different soil and climate conditions (Stevanato et al., 2014). Commonly, in the topsoil of arable land, the soil $\mathrm{C} / \mathrm{N}$ ratio ranges from 10 to 12 and is always lower in the subsoil. Conventional tillage-based managements that limit the input of fresh organic residues and enhance mineralization of existing soil $\mathrm{OM}$ cause the $\mathrm{C} / \mathrm{N}$ ratio to progres- sively decrease with time (Osman, 2013). It is interesting to note that $\mathrm{C} / \mathrm{N}$ was also in total rather low in the old vineyard, despite it having been treated organically and partly left grass-covered for many years.

The three variables considered together (TOC, TN, C/N) seem to suggest that the organic management carried out in the farm produces only a slight improvement in soil biochemical fertility.

A further difference between the two vineyards was marked by the soil soluble salt concentration, which in the new vineyard averaged lower levels for the whole duration of the trial, though with non-statistically significant differences in 2012 and $2013(P>0.1)$. This was an additional consequence of the mixing action of pre-planting earthworks on soil horizons, given the non-saline nature and relatively lower weathering status of the soil parent material that was incorporated into the topsoil.

\subsection{Soil microbial activity and diversity}

The assessment of the structure of soil bacterial communities by DGGE revealed significant differences between the new and the old vineyard. Interestingly, these differences changed with time; the similarity between the two vineyards, in particular, increased by $10.3 \%$ over the considered period (from $78 \%$ in 2010 to $86 \%$ in 2014). However, as observed for 

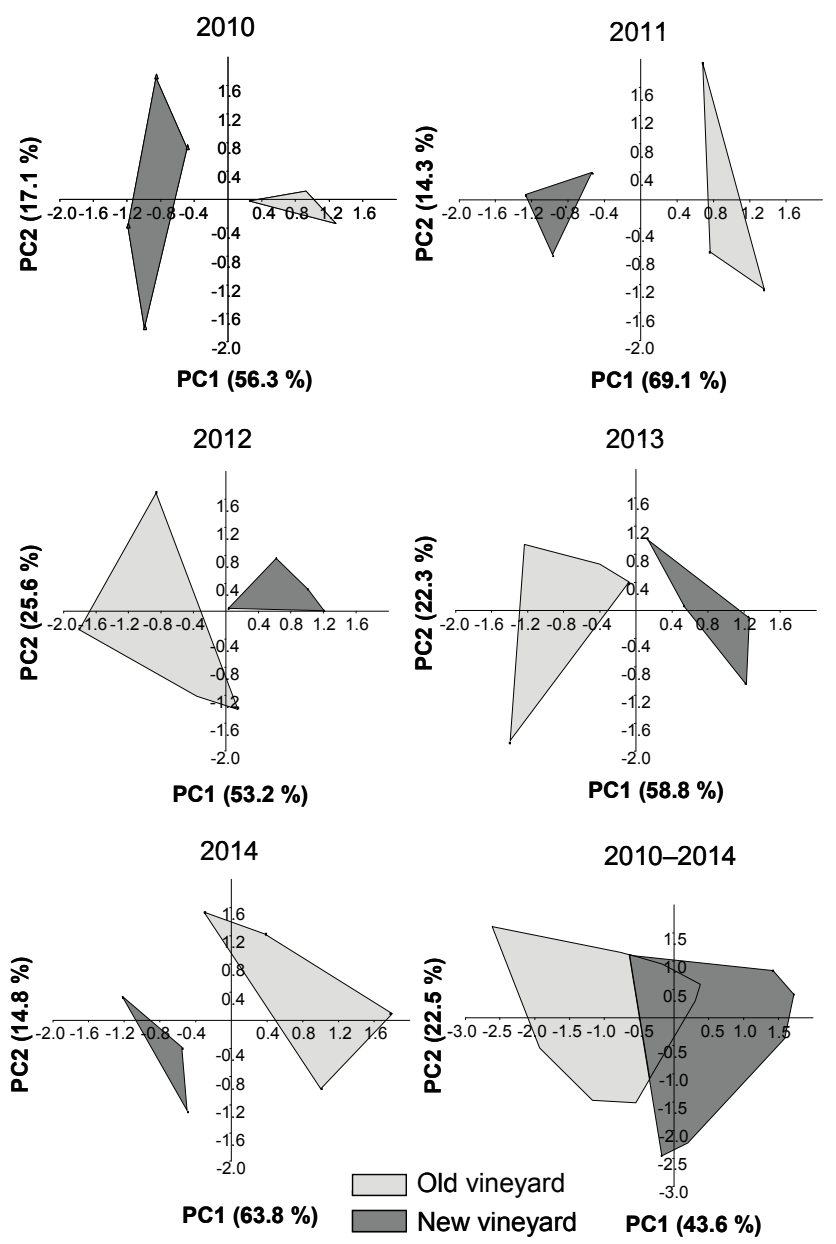

Figure 8. PCA score plots for each year and for the whole study period (not including climate).

all other soil properties, microbial diversity showed a high within-vineyard variability, which in the old vineyard was probably enhanced by the alternate grass-covered/tilled interrow management. Soil variability was well evidenced by microbial respiration (Fig. 6) and PCA (Fig. 9) for each sampling year, especially after 2010 .

At the beginning of the trial (2010), both $H^{\prime}$ and DGGE band number were poorly correlated with other soil properties and, in particular, TOC and TN (Fig. 8), likely due to the short time elapsed since the earthwork treatment. From 2010 to 2013 , microbial diversity was higher in the old vineyard and positively related to TOC, clay content, microbial respiration and other biological indicators. The diversity indices $H^{\prime}$ and $n$. bands appeared, moreover, to be related to the seasonal temperature (Fig. 10), while the close relation between soil $\mathrm{CaCO}_{3}$ and the Simpson index indicates a lower microbial diversity in the presence of higher $\mathrm{CaCO}_{3}$ amounts.

The better homeostatic conditions of the old vineyard soil explain its higher values in terms of microbial diversity and functions as compared to the new vineyard, according to the chemical parameters. This confirms the potential role of microbial diversity as an indicator of recovery processes, as has also been suggested by previous authors (Bezdicek et al., 1996; Seybold et al., 1999). In contrast, microbial respiration, one of the most common and sensitive biological indicators of soil quality, appeared to be affected by other parameters such as soil organic carbon quantity or temperature.

As soil resilience can be quantified experimentally by measuring the rate of recovery of the original pre-disturbance conditions, we calculated the resilience rate based on similarity values. The results indicated a slow but constant increase in similarity between the bacterial communities of the two vineyards, with a recovery rate of about $2.5 \%$ year $^{-1}$ in terms of structural diversity. According to this trend, at least a further 3 years would be needed for the new vineyard to recover a bacterial diversity similar to that of the old vineyard.

\subsection{Soil mesobiology and QBS-ar index}

Among soil organisms that can be affected by the application of different cultivation techniques and crop managements, Annelida and microarthropods are the organisms most representative of mesofauna. In this study, microarthropod density can be considered as a mirror of the aging of the situation tested. It is likely that the densities registered reflected the management adopted and, consequently, their movements into the microscale compartment.

The microarthropod abundance differed considerably between the new and the old vineyard. The new vineyard, after a starting period of very scarce arthropod presence (abundance $<5$ per soil core) following the pre-planting earthworks, showed only moderate signs of recovery, with a relatively stable abundance over time (around 62 per soil core).

Instead, the old vineyard revealed a larger arthropod richness than the new vineyard since the beginning of the trial, with abundance values increasing over time (by $77 \%$ on average per year). As a result, at the end of the trial, the microarthropod abundance in the old vineyard was 2.8 times higher than in the new vineyard. Taking into account climate variables, the microarthropod abundance in the old vineyard appeared closely related to the annual precipitation and, in particular, to the amount of rainfall that occurred during the winter-spring period (from January to April; Spear$\operatorname{man} \rho=1.000, P=0.01$ ). Our results are in agreement with findings by other authors, demonstrating a positive correlation between microarthropod density (mites and springtails) and soil moisture content (Hassall et al., 1986; Chikoski et al., 2006).

It is worth noting that, despite the same climate influence, this relation was not observed in the new vineyard. This was possibly due to a contrasting effect of tillage-induced soil conditions on the development of microarthropod population. In particular, a lower organic matter content, which is a primary source of nutrients for detritivore arthropods, and overall worse soil physical environment, impacted by 

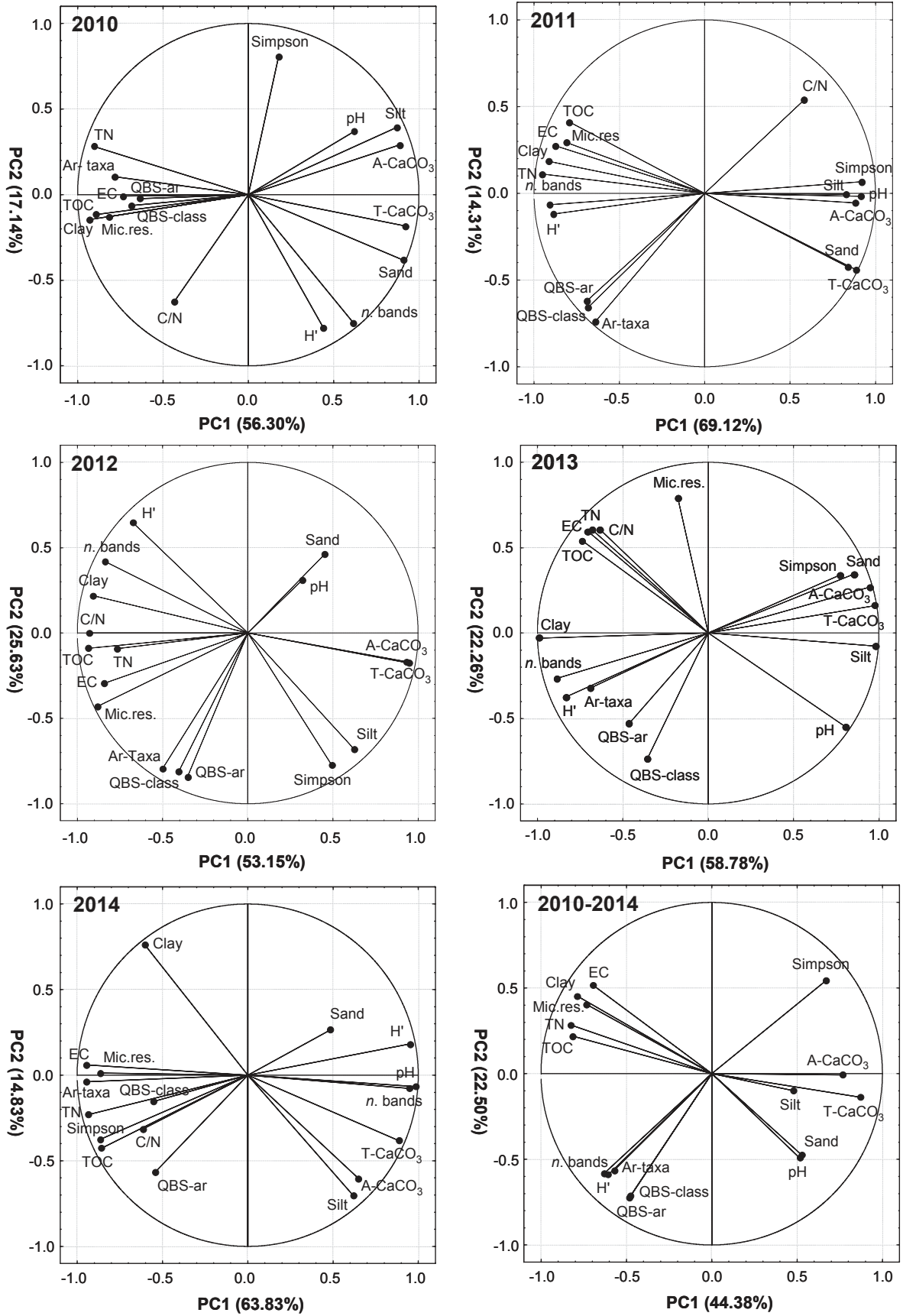

$\mathrm{TOC}=$ soil total $\mathrm{OC} ; \mathrm{TN}=$ soil total $\mathrm{N} ; \mathrm{C} / \mathrm{N}=$ soil $\mathrm{TOC}$ to $\mathrm{TN}$ ratio; $\mathrm{T}-\mathrm{CaCO} 3=$ soil total $\mathrm{CaCO} ; \mathrm{A}-\mathrm{CaCO}_{3}$ = soil active $\mathrm{CaCO} 3$; $\mathrm{EC}$ = soil electrical conductivity; Mic.res. = microbial respiration; $\mathrm{H}^{\prime}$ = Shannon index; Simpson $=$ Simpson index; $n$. bands = number of DGGE bands; Ar-taxa $=$ number of soil microarthropod taxa; QBS-ar = soil biological quality index; QBS-class = soil biological quality class.

Figure 9. PCA loading plots for each year and for the whole study period (not including climate).

pre-planting earthworks and annual tillage practices, created a less suitable habitat for arthropod survival (Kautz et al., 2006; Parisi et al., 2005).

The abundance of mites and springtails varies in a similar way (Narula et al., 1996). For both arthropods, vertical migrations have been observed in response to changes in soil moisture in grassland soils (Hassall et al., 1986). However, their abundance may follow different patterns over time, depending on the life cycle length and reproductive strategy, as well as on their individual tolerance to temperature and moisture in the soil. 


\section{0-2014}

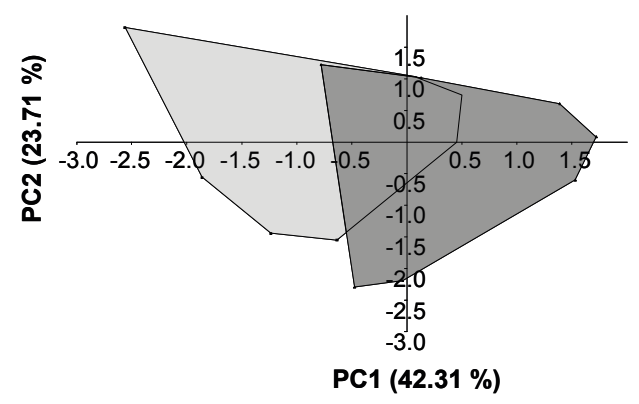

Old vineyard

New vineyard

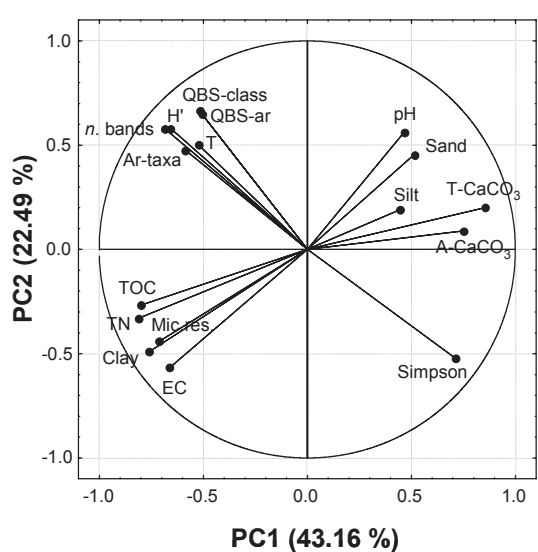

$\mathrm{TOC}=$ soil total $\mathrm{OC} ; \mathrm{TN}=$ soil total $\mathrm{N} ; \mathrm{C} / \mathrm{N}=$ soil $\mathrm{TOC}$ to $\mathrm{TN}$ ratio; $\mathrm{T}-\mathrm{CaCO}_{3}=$ soil total $\mathrm{CaCO}_{3} ; \mathrm{A}-\mathrm{CaCO}_{3}$ = soil active $\mathrm{CaCO}_{3} ; \mathrm{EC}=$ soil electrical conductivity; Mic.res. = microbial respiration; $\mathrm{H}^{\prime}$ = Shannon index; Simpson $=$ Simpson index; $n$. bands $=$ number of DGGE bands; Ar-taxa $=$ number of soil microarthropod taxa; QBS-ar = soil biological quality index; QBS-class = soil biological quality class; $\mathrm{T}=$ temperature .

Figure 10. PCA score and loading plots for the whole 2010-2014 period (including climate).

It is known that the rate of increase in the springtail population is highly dependent on optimal habitat with adequate $\mathrm{N}$ and C supply (Johnston, 2000) and is enhanced by rainfall (Schaefer, 1995; Badejo et al., 1998). In the present study, there was no significant evidence of a relationship between the total microarthropod dynamics and soil $\mathrm{OC}$ and $\mathrm{N}$ changes over time. In the last year, the increase in the springtail population was presumably due to the high rainfall and was particularly evident in the old vineyard, as a result of a larger availability at the soil surface of microenvironments colonized by emi- and epiedaphic forms.

\subsection{Interactions between state factors and soil biology}

The outcomes of the PCA showed a clear separation between the old and the new vineyard along PC1 (Fig. 8), which explained 53 to $69 \%$ of variance over the years $(43.6 \%$ for the overall 2010-2014 period). The results also indicated contrasting contributions to PC1 by soil biological properties (negative loadings) on the one hand, and most of soil physical-chemical properties (positive loadings) on the other (Fig. 9). Apart from the Simpson index and band number, which had different behavior among years, all other variables linked to soil biology, biodiversity and biological quality namely TOC, total N, C/N (except for 2011), $n$. microarthropod taxa, QBS-ar, QBS-ar class, $H^{\prime}$ (except for 2014) and microbial respiration - showed high communality over time and were associated with PC1.

It is worth noting that clay content and electrical conductivity were also associated with PC1. The interaction between clay and microorganisms has been confirmed by other authors (England et al., 1993; Sorensen, 1983), and EC is also well known to affect bacterial metabolism and diversity (Csonka, 1989).

As emphasized by the PCA, soil biological variables consistently appeared to be strongly related to each other. In particular, microbial diversity $\left(H^{\prime}\right.$, band number) were always positively related to QBS-ar, TN availability and clay content, whereas they were negatively related to $\mathrm{CaCO}_{3}$ and sand contents (Fig. 8). With regard to the climate effect, biological diversity was positively related to the temperature, but not to rainfall (which was excluded from the PCA; Fig. 10). Differently, microbial respiration appeared to be more affected by TOC and TN contents rather than by climatic factors.

As previously observed, PC2 played a minor role in the model; however, it tended to differentiate physico-chemical and biochemical variables (TOC, total $\mathrm{N}$, respiration, together with clay and EC) from those which are related to biodiversity and biological quality (QBS-ar, QBS-ar class, $H^{\prime}, n$. microarthropod taxa, $n$. DGGE bands). This would indicate the presence of two different processes: the first one driven by TOC accumulation, which increases biological fertility, and the other one characterized by the increase in biodiversity and biological organization, as a consequence of the progressive adaptation of micro- and mesobiology to the new soil conditions.

In 2010, the new vineyard had a higher spatial heterogeneity compared to the old vineyard; however, since 2011, the latter has shown increasing variability over time.

Finally, it is clearly highlighted by the PCA results that there was no apparent resilience over the considered time span in the new vineyard, which, 5 years after earthworks and 3 years after vine plantation, was still well separated for selected soil functional properties from the older vineyard. 


\section{Conclusions}

To the best of our knowledge, this work is the first attempt to set up an integrated monitoring activity of soil physical, chemical, micro- and mesobiological functions over time in a new vineyard, with the aim to understand their changes in response to pre-planting earthworks and assess a possible recovery to their original or a new equilibrium status. The results demonstrate that earthworks caused strong modifications in the topsoil physical and chemical properties and negatively impacted soil biological communities, at both the microbial and the mesofauna level.

The comparison with a neighboring old vineyard planted on the same soil type evidenced that, 4 years after planting, most soil properties are still significantly different and only biodiversity tends to converge. It is expected that biodiversity in the two soils will be similar in about 3 years - that is, 8 years after the earthworks and 6 years after vine plantation. For the other soil functions it is difficult to predict the resilience time, also because the soil under the relatively older vineyard has not yet reached, 14 years after vine plantation, a steady state for several chemical properties.

The partial permanent grass cover in the old vineyard did not result in a significant improvement in soil biology, and the organic farming itself appeared to be scarcely effective in enhancing the recovery process, probably because of the small amount of supplied compost. Instead, it seems to be plausible that the different soil organic matter content and biology between the new and old vineyard were mainly related to the different vine development and plant residue availability.

In conclusion, from the overall results of this work it can be stated that, in these specific soil and environmental conditions, which are, however, representative of many premium viticultural farms, soils with very poor biological fertility - like those disturbed by pre-planting earthworks - need a rather long time to restore their functions, probably longer than the time needed to reach a commercially acceptable level of grape production.

The perspective of our research is to continue the annual soil monitoring and multidisciplinary analysis and, at the same time, to start monitoring vine plants and grass biomass, at least until the grape yield of the new and old vineyard is similar.

Acknowledgements. The authors are grateful to Massimiliano Biagi, agronomist at the Barone Ricasoli farm, for the excellent technical assistance. This research was funded by the CRA Consiglio per la Ricerca in Agricoltura e l'Analisi dell'Economia Agraria (project ISSUOVINO) and by the Barone Ricasoli farm.

Edited by: E. Vaudour

\section{References}

Andrenelli, M. C., Fiori, V., and Pellegrini, S.: Soil particle-size analysis up to $250 \mu \mathrm{m}$ by X-ray granulometer: device set-up and regressions for data conversion into pipette-equivalent values, Geoderma, 192, 380-393, 2013.

Badejo, M. A., Nathaniol, T. I., and Tian, G.: Abundance of springtails (Collembola) under four agroforestry tree species with contrasting litter quality. Biol. Fert. Soils, 27, 15-20, 1998.

Bazzoffi, P. and Tesi, P. C.: Effectiveness of the GAEC standard of cross compliance Prohibition of performing unauthorized land levelling on soil erosion control, Italian J. Agronomy, 6, 25-34, 2011.

Bazzoffi, P., Abbattista, F., Vanino, S., and Pellegrini S.: Impact of land levelling for vineyard plantation on soil degradation in Italy, Bollettino della Societa Geologica Italiana, 6, 191-199, 2006.

Bezdicek, D., Papendick, R. I., and Lal, R.: Importance of soil quality to health and sustainable land management, in: Methods for assessing soil quality, edited by: Doran, J. W. and Jones, A. J., SSSA Spec. Publ. 49, Soil Sci. Soc. Am., Madison, WI, 1-18, 1996.

Blanco-Canqui, H. and Lal, R.: Principles of Soil Conservation and Management, Springer, New York, 617 p., 2008.

Bloem, J., Benedetti, A., and Hopkins, D. W.: Microbiological methods for assessing soil quality, Wallingford, UK, Cabi Publishing, ISBN 0-85199-098-3, 2006.

Brussaard, L., Behan-Pelletier, V. M., Bignell, D., Brown, V. K., Didden, W., Folgarait, P., Fragoso, C., Wall Freckman, D., Gupta, V. V. S. R., Hattori, T., Hawksworth, D. L., Klopatek, C., Lavelle, P., Malloch, D. W., Rusek, J., Söderström, B., Tiedje, J. M., and Ross, A. V.: Biodiversity and ecosystem functionning in soil, Ambio, 26, 563-570, 1997.

Chikoski, J. M., Ferguson, S. H., and Meyer, L.: Effects of water addition on soil arthropods and soil characteristics in a precipitation-limited environment, Acta Oecologica, 30, 203211, 2006.

Costantini, E. A. C. and Barbetti, R.: Environmental and visual impact analysis of viticulture and olive tree cultivation in the province of Siena (Italy), European J. Agronomy, 28, 412-426, 2008.

Costantini, E. A. C., Bucelli, P., and Priori, S.: Quaternary landscape history determines the soil functional characters of terroir, Quat. Int., 265, 63-73, 2012.

Costantini, E. A. C., Agnelli, A., Bucelli, P., Ciambotti, A., Dell'Oro, V., Natarelli, L., Pellegrini, S., Perria, R., Priori, S., Storchi, P., Tsolakis, C., and Vignozzi, N.: Unexpected relationships between $\delta 13 \mathrm{c}$ and wine grape performance in organic farming, J. Int. Sci. Vigne Vin, 47, 269-285, $2013 \mathrm{a}$.

Costantini, E. A. C., Fantappié, M., and L'Abate, G.: Climate and pedoclimate of Italy, in: The Soils of Italy, edited by: Costantini, E. A. C. and Dazzi, C., World Soils Book Series, Springer, Dordrecht, Heidelberg, London, New York, 19-37, doi:10.1007/97894-007-5642-7, 2013b.

Csonka, L. N.: Physiological and genetic responses of bacteria to osmotic stress, Microbiol. Rev., 53, 121-147, 1989.

Culliney, T. W.: Role of Arthropods in Maintaining Soil Fertility, Agriculture, 3, 629-659, doi:10.3390/agriculture3040629, 2013.

D’Avino, L.: Esposizione del metodo di Vittorio Parisi per la valutazione della Qualità Biologica del Suolo (QBS) e proposta di 
standardizzazione delle procedure, CD ROM, Museo di Storia Naturale di Parma, Italy, 2002.

Egli, M. and Fitze, P.: Quantitative aspects of carbonate leaching of soils with differing ages and climates, Catena, 46, 35-62, 2001.

Eilers, K. G., Debenport, S., Anderson, S., and Fierer, N.: Digging deeper to find unique microbial communities: The strong effect of depth on the structure of bacterial and archaeal communities in soil, Soil Biol. Biochem., 50, 58-65, 2012.

England, L. S., Lee, H., and Trevors, J. T.: Bacterial survival in soil: effect of clays and protozoa, Soil Biol. Biochem., 25, 525-531, 1993.

Fabiani, A., Gamalero, E., Castaldini, M., Cossa, G. P., Musso, C., Pagliai, M., and Berta, G.: Microbiological polyphasic approach for soil health evaluation in an Italian pollutted site, Sci. Tot. Environ., 407, 4954-4964, 2009.

Felske, A. and Akkermans, A. D. L.: Spatial homogeneity of abundant bacterial 16S rRNA molecules in grassland soils, Microb. Ecol., 36, 31-36, 1998.

Fierer, N., Schimel, J. P., and Holden, P. A.: Variations in microbial community composition through two soil depth profiles, Soil Biol. Biochem., 35, 167-176, 2003.

Garcia-Ruiz, J. M.: The effects of land uses on soil erosion in Spain: A review, Catena, 81, 1-11, 2010.

Hargreaves, G. H. and Samani, Z. A.: Estimating potential evapotranspiration, J. Irrig. Drain. Div., 108, 225-230, 1982.

Hassall, M., Visser, S., and Parkinson, D.: Vertical migration of Onychiurus subtenuis (Collembola) in relation to rainfall and microbial activity, Pedobiologia, 29, 175-182, 1986.

Huber, L., Eisenbeis, G., Porten, M., and Ruhl, E. H.: The influence of organically managed vineyard-soils on the phylloxerapopulations and the vigour of grapevines, Ac. Horticulturae, 617, 55-59, 2003.

Isermeyer, H.: Eine einfache Methode zur Bestimmung der Bodenatmung und der Karbonate im Boden, Z. Pflanzenernaehr. Bodenkd., 56, 26-38, 1952.

ISTAT: Statistical data editing, Essays no. 6, Rome, Itituto Nazionale di Statistica, ISBN: 88-458-0284-12000, 2000.

IUSS Working Group WRB: World Reference Base for Soil Resources, World Soil Resources Reports No. 106, FAO, Rome, 2014.

Johnston, J. M.: The contribution of microarthropods to aboveground food webs: a review and model of belowground transfer in a coniferous forest, Am. Midland Nat., 143, 226-238, 2000.

Kautz, T., López-Fando, C., and Ellmer, F.: Abundance and biodiversity of soil microarthropods as influenced by different types of organic manure in a long-term field experiment in Central Spain, Appl. Soil Ecol., 33, 278-285, 2006.

Lal, R.: Degradation and resilience of soils, Phil. Trans. R. Soc. Lond. B, 352, 997-1010, 1997.

Lamb, R. O.: Geotechnical aspects of leaching of carbonates from loessial soils, in: Physico-chemical Aspects of Soil and Related Materials, edited by: Hoddinott, K. B. and Lamb, R. O., ASTM STP 1095, American society for testing and materials Physic, Philadelphia, 29-43, 1990.

Le Bissonnais, Y., Montier, C., Jamagne, M., Daroussin, J., and King, D.: Mapping erosion risk for cultivated soil in France, Catena, 46, 207-220, 2002.

Le Bissonnais, Y., Blavet, D., De Noni, G., Laurent, J. Y., Asseline, J., and Chenu, C.: Erodibility of Mediterranean vineyard soils: relevant aggregate stability methods and significant soil variables, European J. Soil Sci., 58, 188-195, 2007.

Loeppert, R. H. and Suarez, D. L.: Carbonate and gypsum, in: Methods of soil analysis, Part 3: Chemical methods, edited by: Sparks, D. L., SSSA and ASA, Madison, WI, 437-474, 1996.

Martínez-Casasnovas, J. A. and Concepción Ramos, M.: Soil alteration due to erosion, ploughing and levelling of vineyards in north east Spain, Soil Use Manage., 25, 183-192, 2009.

Menta, C., Leoni, A., Bardini, M., Gardi, C., and Gatti, F.: Nematode and microarthropod com-munities: comparative use of soil quality bioindicators in covered dump and natural soils, Environ. Bioind., 3, 35-46, 2008.

Muyzer, G. and Smalla, K.: Application of denaturing gradient gel electrophoresis (DGGE) and temperature gradient gel electrophoresis (TGGE) in microbial ecology, Antonie van Leeuwenhoek, 73, 127-141, 1998.

Nannipieri, P., Ascher, J., Ceccherini, M., Landi, L., Pietramellara, G., and Renella, G.: Microbial diversity and soil functions, European J. Soil Sci., 54, 655-670, 2003.

Narula, A., Vats, L. K., and Handa, S.: Collembolas and mites of deciduous forest stand, Ind. J. For., 21, 147-149, 1998.

Osman, K. T.: Soils: Principles, properties and management, Springer, Dordrecht, 274 p., 2013.

Paoletti, M. G. and Bressan, M.: Soil invertebrates as bioindicators of human disturbance, Crit. Rev. Plant Sci., 15, 21-26, 1995.

Parisi, V.: La qualità biologica del suolo. Un metodo basato sui microartropodi, Acta Naturalia de l'Ateneo Parmense, 37, 97-106, 2001.

Parisi, V., Menta, C., Gardi, C., Jacomini, C., and Mozzanica, E.: Microarthropod communities as a tool to assess soil quality and biodiversity: a new approach in Italy, Agric., Ecosys. Env., 105, 323-333, 2005.

Probst, B., Schuler, C., and Joergensen, R. G.: Vineyard soils under organic and conventional management - Microbial biomass and activity indices and their relation to soil chemical properties, Biol. Fert. Soils, 44, 443-450, 2008.

Ramos, M. C. and Martinez-Casasnovas, J. A.: Nutrient losses by runoff in vineyards of the Mediterranean Alt Penedès region (NE Spain) Agriculture, Ecosyst. Environ., 113, 356-363, 2006.

Ramos, M. C. and Martínez-Casasnovas, J. A.: Soil loss and soil water content affected by land levelling in Penedès vineyards, NE Spain, Catena, 71, 210-217, 2007.

Rawnsley, B.: Assessment of soil health in vineyards, Ac. Horticulturae, 1018, 417-424, 2014.

Reinecke, A. J., Albertus, R. M. C., Reinecke, S. A., and Larink, O.: The effects of organic and conventional management practices on feeding activity of soil organisms in vineyards, African Zool., 43, 66-74, 2008.

Schaefer, M.: Interspecific interactions in the soil community, Acta Zool. Fennica, 196, 101-106, 1995.

Seddaiu, G., Porcu, G., Ledda, L., Roggero, P. P., Agnelli, A., and Corti, G.: Soil organic matter content and composition as influenced by soil management in a semi-arid Mediterranean agrosilvo-pastoral system, Agric. Ecosyst. Environ., 167, 1-11, 2013.

Sequi, P. and De Nobili, M.: Carbonio organico, in: Metodi di Analisi Chimica del Suolo, edited by: Angeli, F., Ministero per le Politiche Agricole e Forestali, Osservatorio Nazionale Pedologico e per la Qualità del Suolo, VII.1, 1-13, 2000. 
Seybold, C. A., Herrick, J. E., and Brejda, J. J.: Soil resilience: a fundamental component of soil quality, Soil Sci., 164, 224-234, 1999.

Sharp-Heward, S., Almond, P., and Robinson, B.: Soil disturbance and salinisation on a vineyard affected by landscape recontouring in marlborough, new zealand, Catena, 122, 170-179, 2014.

Sorensen, L. H.: The infuence of stress treatments on the microbial biomass and the rate of decomposition of humified matter in soils containing different amounts of clay, Plant Soil, 75, 107-119, 1983.

Stevanato, P., Concheri, G., Squartini, A., Saccomani, M., Piffanelli, P., Fricano, A., Angelini, E., and Fornasier, F.: Soil biological and Biochemical traits linked to nutritional status in grapevine, J. Soil Sci. Plant Nut., 14, 421-432, 2014.

Van Leeuwen, C. and Seguin, G.: The Concept of Terroir in Viticulture, J. Wine Res., 17, 1-10, 2006.
Van Leeuwen, C., Friant, P., Choné, X., Tregoat, O., Koundouras, S., and Dubourdieu, D.: Influence of Climate, Soil, and Cultivar on Terroir, Am. J. Enol., 55, 207-217, 2004.

Vaudour, E.: The quality of grapes and wine in relation to geography: notions of terroir at various scales, J. Wine Res., 13, 117 $141,2002$.

Wardle, D. A.: Communities and Ecosystems: Linking the Aboveground and Belowground Components, Princeton University Press, New Jersey, 408 pp., 2002.

White, R. E.: Soils for fine wines, Oxford University Press, New York, 312 p., 2003.

Yan, S., Singh, A. N., Fu, S., Liao, C., Wang, S., Li, Y., Cui, Y., and Hu, L.: A soil fauna index for assessing soil quality, Soil Biol.Bioch., 47, 158-165, doi:10.1016/j.soilbio.2011.11.014, 2012. 